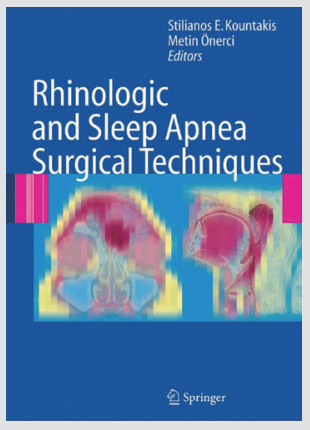

\title{
Rhinologic and Sleep Apnea Surgical Techniques
}

\author{
Stilianos E. Kountakis, Metin Önerci
}

2007년에 Stilianos E. Kountakis와 Metin Onerci에 의해 출판된 이 책은 크게 부비동과 수면 무호흡 분야에 대한 수술적 치료에 중점을 두고 이 분야에 관심이 있는 이비인후과 의사를 대상독자로 하였다. 각 세부분야별로 활발하게 활동 중인 이비 인후과 의사들이 집필을 담당하여 필요한 내용들이 빠짐없이 간결하게 기술되어 있다.

부비동 부분에서는 해부학에서 시작하여 수술에 이용되는 기구들, 마취 방법 등에 대한 자세한 기술이 있고 각 부비동별로 질환의 경중에 따라 내시경적 접근 방법과 기존의 외비 접근 방식에 대해 기술되어 있다. 후반부에는 비부비동 종양의 내시경 적 치료, 소아부비동염의 치료, 부비동 재수술에 있어서 고려할 점 등에 대하여 기술이 잘 되어 있다. Image-guided surgery와 최근 시도되고 있는 balloon sinuplasty의 술식 소개 및 적합한 환자 선택방법에 대해서도 기술되어 있다. 이해를 돕기 위해 많 은 삽화, 사진을 통해 수술에 경험이 많지 않은 전공의나 젊은 임상의에게 좋은 안내 책자가 될 것으로 생각한다. 또한 이미 비부비동 수술에 경험이 많은 중견 의사들도 부분별로 점검이 필요할 때 읽으면 도움이 될 것으로 생각한다.

수면 무호흡 부분에서는 비강, 구강, 비인두, 하인두에 이르기까지 좁아진 기도를 넓힐 수 있는 수술적 방법에 대하여 역시 삽 화와 사진이 함께 잘 기술되어 있다. 현재는 잘 쓰이지 않는 radiofrequency of palate, palatal implants, injection snoreplasty 등에 대한 기술도 있어 수면 무호흡의 수술 방법이 어떻게 발전되어 왔는지를 이해하는 데도 도움이 된다. 수술적 치료가 실패했 을 때 생각해야 될 가능한 원인들, 수술의 합병증과 이에 대한 대처방법 등의 기술도 많은 도움이 될 것으로 생각한다.

부록으로 제공되는 DVD에는 삽화나 사진으로 나타내기 어려운 수술방법을 동영상을 통해 이해를 돕고자 했다. 각 chapter 별로 저자가 다르지만 집필방식을 통일하여 이해에 도움을 주는 것도 이 책의 장점이다. 나날이 빠른 속도로 발전하고 있는 의학 지식과 새로운 진단 및 수술기법들이 등장하는 추세를 감안하면 2007년에 출판된 이 책이 벌써 고전이 되어가는 느낌이 있지 만 이비인후과 의사가 갖추어야 할 기본적인 배경 지식이 잘 기술되어 있기 때문에 이 분야에 관심을 가지고 시작하려는 이비 인후과 의사에게 유용한 참고도서가 될 것으로 생각한다.

대한이비인후과학회 간행위원회 